Historia de las ideas psiquiátricas: el naturalismo psiquiátrico Jorge J. Saurí Buenos Aires, Lohlé-Lumen

\title{
O naturalismo psiquiátrico
}

\author{
Mario Eduardo Costa Pereira
}

Em 1969, o psiquiatra, psicanalista e professor de psicopatologia argentino, dr. Jorge J. Saurí, publicou em Buenos Aires um dos mais importantes escritos críticos já produzidos pela psiquiatria latinoamericana: Historia de las ideas psiquiátricas, o qual viria fazer parte da formação de todas as gerações subseqüentes de psicopatólogos em nosso continente

El naturalismo psiquiátrico, que aqui apresentamos, constitui, na verdade, a primeira parte revista e aumentada do texto original. A segunda parte, intitulada La crisis de la psiquiatría, também está 
sendo publicada em um volume separado e atualizado pelas Ediciones LohléLumen, de Buenos Aires.

O eixo orientador dessa obra é a constituição da concepção do homem como um Homo natura - para utilizar uma expressão cara a Binswanger - no pensamento e na clínica psiquiátrica. O livro examina, com elegância e erudição, o desenvolvimento, a partir das revoluções estéticas do Quattrocento, dos supostos básicos que sustentam, ainda hoje, as práticas psiquiátricas sobre uma visão naturalista da doença mental.

A própria noção de "natureza" é resgatada em sua ambigüidade de "essência" e de "conjunto dos existentes", submetidos a ordens e necessidades inocentes. O professor Saurí mostra como, a partir da Scienza Nuova de Vico, as dimensões de tempo e espaço passaram a ser concebidas como as coordenadas fundamentais do Real e como, correlativamente, a tarefa de ver os objetos de forma clara e distinta, inscritos de forma distinta nessas coordenadas, torna-se o próprio fundamento da ciência. A luz e as metáforas da "iluminação" passam a constituir a forma privilegiada de se explicar o acesso racional às coisas.

Com Galileu, acrescenta-se a exigência da expressão matemática das regularidades observadas nesses objetos. A ciência galileica não se interessa pela essência das coisas, mas pelo que com elas acontece em seus deslocamentos. Isso introduz um corte radical em relação às ciências românica e gótica, que se limitavam ao comentário dos dados revelados, uma vez que seu mundo imediato era o da fé. Galileu introduz uma nova atitude frente aos fatos: é necessário vêlos claramente, compará-los, testá-los experimentalmente e daí deduzir a explicação. Essa deve poder expressar-se matematicamente. O cálculo e a medição constituem o fundamento mesmo dessa abordagem racional do natural.

O Realismo subjacente ao naturalismo dá por suposta a realidade dos fatos estudados. É justamente a invariabilidade das coisas o que garantiria o conhecimento objetivo. Com o Positivismo, tal concepção vai ainda mais longe, só considerando como reais os elementos mensuráveis. Dessa forma, o método científico tratará da realidade exclusivamente como um "problema", ou seja, como remetendo a incógnitas susceptíveis de serem resolvidas racionalmente. Eliminamse as dimensões de transcendência e de mistério.

Tais coordenadas epistemológicas, quando transpostas para o campo da "natureza humana", levam a uma aproximação da questão do sofrimento psíquico como um dado objetivável. A "loucura", por sua vez, passará a ser delimitada pela categoria de "doença mental". Aqui, o termo "doença" é a própria expressão do "natural": é algo que vem "de fora", invasora, ativa, agressiva, exterior, incidindo sobre um "paciente" (passivo, inocente, invadido, caracterizado por um "dentro"). O termo "alienação" exprime, pois, não apenas a relação do indivíduo 
doente com o mundo dos normais, mas sua própria condição de exclusão interna em relação a si mesmo e a seu sofrimento.

$\mathrm{O}$ percurso do texto é o de tirar as conseqüências de tais pressupostos tanto para as ciências que se ocupam do psíquico e de suas formas de padecimento quanto para os modos assistenciais e terapêuticos deles decorrentes.

O livro termina com passagens de textos fundamentais da história da psiquiatria que ilustram de maneira paradigmática os pressupostos epistêmicos estudados e colocados em evidência pelo professor Saurí (entre eles estão The Physiology and Pathology of Mind, de Maudsley e Traité médico-philosophique sur l'aliénation mentale, de Pinel).

Finalmente, é estabelecida uma cronologia que coteja os grandes acontecimentos filosóficos, culturais e científicos desde 1700 , com os principais eventos da história da psiquiatria, permitindo melhor situá-los no contexto da história das idéias do Ocidente.

Um livro clássico e reconhecido há trinta anos como El naturalismo psiquiátrico não necessita ser recomendado. É preciso, apenas, na avalanche contemporânea da ideologia de uma ciência vitoriosa, relembrar sua importância crítica e relativizante. 